\title{
Poverty, inequality and social disparities during China's economic reform
}

\author{
By David Dollar \\ World Bank Country Director, China
}

\begin{abstract}
China has been the most rapidly growing economy in the world over the past 25 years. This growth has fueled a remarkable increase in per capita income and a decline in the poverty rate from $64 \%$ at the beginning of reform to $10 \%$ in 2004 . At the same time, however, different kinds of disparities have increased. Income inequality has risen, propelled by the rural-urban income gap and by the growing disparity between highly educated urban professionals and the urban working class. There have also been increases in inequality of health and education outcomes. Some rise in inequality was inevitable as China introduced a market system, but inequality may have been exacerbated rather than mitigated by a number of policy features. Restrictions on ruralurban migration have limited opportunities for the relatively poor rural population. The inability to sell or mortgage rural land has further reduced opportunities. China has a uniquely decentralized fiscal system that has relied on local government to fund basic health and education. The result has been that poor villages could not afford to provide good services, and poor households could not afford the high private costs of basic public services. Ironically, the large trade surplus that China has built up in recent years is a further problem, in that it stimulates an urban industrial sector that no longer creates many jobs while restricting the government's ability to increase spending to improve services and address disparities. The government's recent policy shift to encourage migration, fund education and health for poor areas and poor households, and rebalance the economy away from investment and exports toward domestic consumption and public services, should help reduce social disparities.

World Bank Policy Research Working Paper 4253, June 2007

The Policy Research Working Paper Series disseminates the findings of work in progress to encourage the exchange of ideas about development issues. An objective of the series is to get the findings out quickly, even if the presentations are less than fully polished. The papers carry the names of the authors and should be cited accordingly. The findings, interpretations, and conclusions expressed in this paper are entirely those of the authors. They do not necessarily represent the view of the World Bank, its Executive Directors, or the countries they represent. Policy Research Working Papers are available online at http://econ.worldbank.org.
\end{abstract}




\section{Introduction}

China has been the most rapidly growing economy in the world over the past 25 years. This growth has led to an extraordinary increase in real living standards and to an unprecedented decline in poverty. The World Bank estimates that more than $60 \%$ of the population was living under its \$1 per day (PPP) poverty line at the beginning of economic reform. That poverty headcount ratio had declined to $10 \%$ by 2004 , indicating that about 500 million people have been lifted out of poverty in a generation.

At the same time, the phenomenal rate of change has brought with it different kinds of stresses. China faces serious natural resource scarcity and environmental degradation. It has also seen growing disparities of different kinds as people in different parts of the country and with different characteristics have benefited from the growth at different rates. Growing disparities, and policy measures that might mitigate them, are the main focus of this paper. In the next section I briefly review the main elements of China's economic reform and its impact on per capita income and the poverty level.

Section 3 then documents different kinds of disparities that have emerged. Starting from the pre-reform situation, some increase in income inequality was inevitable, as coastal urban locations benefited first from the opening policy and as the small stock of educated people found new opportunities. The main point of the section, however, is that particular features of Chinese policy may have exacerbated rather than mitigated growing disparities. The household registration (hukou) system kept rural-urban migration below what it otherwise would have been, and contributed to the development of one of the largest rural-urban income divides in the world. Weak tenure over rural land also limited the ability of peasants to benefit from their primary asset.

Aside from income inequality, there has also been an increase in inequality of educational outcomes and health status. These developments are partly the result of China's uniquely decentralized fiscal system, in which local government has been primarily responsible for funding basic health and education. Poor localities have not been able to fund these services, and poor households have not been able to afford the high private cost of basic education and healthcare.

Section 4 argues that the large trade surplus that has emerged in China exacerbates these inequalities and makes them harder to address. The trade surplus 
stimulates the urban manufacturing sector, which is already relatively well off. It limits the government's scope to increase funding for public services such as rural health and education. A rebalancing of China's production away from investment and exports and toward domestic consumption and services would be good for the country's long-term macroeconomic health, good for the world economy, and good for the relatively poor in China.

The concluding section looks at some specific policy options for limiting and even reversing the growing disparities in China. Since 2004 the government has introduced measures to reduce disparities including relaxation of the hukou system, abolition of the agricultural tax, and increased central transfers to fund health and education in rural areas.

\section{Economic reform and poverty reduction}

China has maintained a high growth rate for more than 25 years since the beginning of economic reform in 1978, and this sustained growth has generated a huge increase in average living standards. It is useful to begin with a short review of how China was able to produce this growth. China had many characteristics in common with the rest of developing Asia 25 years ago: large population, low per capita income, and resource scarcity on a per capita basis. In general, developing Asia has grown well, but China’s performance really stands out. In the 15 years from 1990-2005, for example, China averaged per capita growth of 8.7\%; India, 4\%; and developing Asia other than China and India, 2.7\%. (Developing Asia outside of China and India has 850 million people; the main population centers are Pakistan, Bangladesh, Vietnam, Indonesia, Myanmar, the Philippines, and Thailand.)

Why has China grown so much faster than the other parts of developing Asia? This is obviously a complex question involving many factors. I would highlight three factors in particular that help to explain the divergent growth performances. First, China had a better base of human capital compared to its neighbors. Second, over this period China has been more open to foreign trade and investment than India or most other Asian developing countries. Third, China has created a better investment climate for the private sector than India, which in turn had a better climate than the rest of developing Asia on 
average. The qualifier "on average" is important because Thailand, for example, had quite a good investment climate and grew well, but it is relatively small, dwarfed in size by Indonesia, Bangladesh, and Pakistan.

In the area of human capital, it is important to note that China's advantage has historical roots. Already in 1870, 21\% of adults in China were literate - since nearly all of these would have been males, this means that about $40 \%$ of adult males were literate. In South Asia the literacy rate in 1870 was 3\% of the adult population, about the same as in Africa. Latin America had a literacy rate of 15\% in 1870 (Morrisson and Murtin, 2005). In 1990, even though China was poorer than India or its other neighbors, it had a more educated population. Average years of schooling of the adult population in China was 5.2 years in 1990, compared to 3.7 in India or 3.5 for the rest of developing Asia (Barro and Lee, 2000). The superior human capital of China can be seen as well in infant mortality data, which are a good summary indicator of health status. In 1990 China's infant mortality rate was 38 per 1000, far below India's 80 or the rest of developing Asia's 69 (Table 1). Despite its good human capital, in 1990 China had about the same per capita income as Bangladesh, India, Pakistan, and Vietnam, and was substantially poorer than Indonesia, Philippines, and Thailand. It is hard to get reliable data on wages, but the available data suggest that China had wages somewhat lower than those in Bangladesh, India, and Pakistan, and far behind those in the more advanced Asian developing countries (Table 2).

The Chinese refer to their reform program as "Gai ge kai fang," which translates as "change the system, open the door." "The whole reform program is often referred to in brief as the "open door policy." This highlights that a key component of Chinese reform has been trade liberalization and opening up to direct foreign investment, but not opening the capital account more generally to portfolio flows. By 1990 China's economy was far more open than those of the other low-wage countries in Asia: China's average import tariff was 40\%, well below those of Bangladesh (94\%), India (82\%), or Pakistan (65\%). Thailand (40\%) had the same average tariff rate in 1990; the Philippines (28\%) and Indonesia (21\%) were more open still, but with significantly higher wages they were not competing directly with China (Table 2). After joining the WTO China's average tariffs have dropped below $10 \%$, and to around $5 \%$ for manufactured imports. ${ }^{2}$ It initially 
welcomed foreign investment into "special economic zones," but it is important to note that some of these were very large, amounting to urban areas of 20 million people or more. The positive impact of foreign investment in these locations led to a more general opening up of the economy to foreign investment, with the result that China has become the largest recipient of direct investment flows in recent years. Thus, compared to other labor-abundant countries in Asia, China has been more open to foreign trade and investment.

The opening up measures would not have had such substantial impact if they had not been accompanied by improvements in investment climate. This is probably one of the least understood features of China's recent development. There are literally dozens of Chinese coastal cities that have developed quite good investment climates. In these cities the private sector accounts for $90 \%$ or more of manufacturing assets and production. A genuine Chinese private sector has emerged that is highly profitable: in 2005 average pretax rate of return for domestic private firms was the same as that for foreign-invested firms (Dollar and Wei, 2006). World Bank investment climate surveys have documented the differences in the objective conditions of production in Chinese cities, compared to ones elsewhere in developing Asia. For example, firms lose a lot of output as a result of unreliable power supply: 3.3\% of output in Indonesia, $4.9 \%$ in Pakistan, $5.9 \%$ in Philippines, 7.9\% in India. The figure for coastal Chinese cities was 1.0\% (Table 3). Similarly, most manufacturing firms are importing some parts and material: customs clearance time for imports is low in Chinese cities (3.2 days) compared to those in Indonesia (4.8), India (6.6), Philippines (7.2), Bangladesh (10.6), or Pakistan (17.1). ${ }^{3}$ On a whole range of practical matters that affect production, Chinese coastal cities outperform the best locations in Bangladesh, India, Indonesia, Pakistan, and the Philippines. The only large Asian countries that have similarly good investment climate indicators are Thailand and Vietnam, both of which have grown quite well - though not as fast as China - in the recent period.

In summary, China, India, and the rest of developing Asia entered this recent era of globalization with similar per capita GDP and wage levels. But China has done more to open its economy to the global market, while significant numbers of its coastal cities have created sound investment climates for private investment. The result has been a 
remarkable dynamic of growth. India has followed a similar path, but more slowly in terms of opening up the economy and with less success in creating good investment climates. ${ }^{4}$ The rest of developing Asia has some pockets of notable success such as Malaysia, Thailand, and Vietnam, but other large population centers such as Indonesia, Bangladesh, Pakistan, and the Philippines have been held back, primarily by poor investment climates and weaker connections to the global market.

China's sustained growth fueled historically unprecedented poverty reduction.

The World Bank uses a poverty line based on household real consumption (including consumption of own-produced crops and other goods), set at \$1 per day measured at Purchasing Power Parity. In most low-income countries this amount is sufficient to guarantee each person about 2000 calories of nutrition per day, plus other basic necessities. In contemporary China this line corresponds to about 888 RMB per year. Based on household surveys, we estimate that the poverty rate in China in 1981 was 64\% of the population. This rate declined to $10 \%$ in 2004, indicating that about 500 million people have climbed out of poverty during this period (Figure 1).

This poverty reduction has occurred in waves. The shift to the household responsibility system propelled a large increase in agricultural output, and poverty was cut in half over the short period from 1981 to 1987. From 1987 to 1993 poverty reduction stagnated, then resumed again. From 1996 to 2001 there was once more relatively little poverty reduction. Since China joined the WTO in 2001, however, poverty reduction resumed at a very rapid rate, and poverty was cut by a third in just three years.

\section{Economic reform and increased inequality}

China's growth has been so rapid that virtually every household has benefited significantly, fueling the impressive drop in poverty. However, different people have benefited to very different extents, so that inequality has risen during the reform period. This is true for inequality in household income or consumption, as well as for inequality in important social outcomes such as health status or educational attainment. Concerning household consumption, the Gini measure of inequality increased from 0.31 at the beginning of reform to 0.45 in 2004, a level similar to that of the U.S. To some extent 
this rise in inequality is the natural result of the market forces that have generated the strong growth; but to some extent it is "artificial” in the sense that various government policies exacerbate the tendencies toward higher inequality, rather than mitigate them. Increasing inequality could be halted, even reversed, by changing some of these policies.

\section{A. “Development must be inegalitarian"}

The Nobel-prize-winning economist Sir Arthur Lewis noted five decades ago that “development must be inegalitarian because it does not start in every part of the economy at the same time” (Lewis, 1954). China classically manifests two of the characteristics of development that Lewis had in mind: rising return to education and rural-urban migration. As an underdeveloped country, China began its reform with relatively few highly educated people, and with a small minority of the population (20\%) living in cities, where labor productivity was about twice the level as in the countryside.

In pre-reform China there was very little return to education manifested in salaries. Cab drivers and college professors had similar incomes. Economic reform has created a labor market in which people can search for higher pay, and one non-surprising result of this is that salaries for educated people have gone up dramatically. In the short period between 1988 and 2003, the wage returns to one additional year of schooling increased from $4 \%$ to $11 \%$ (Figure 2). This development initially leads to higher overall inequality, because the initial stock of educated people is small and they are concentrated at the high end of the income distribution. But if there is reasonably good access to education, then over time a greater and greater share of the population will become educated, and that will ultimately tend to reduce inequality.

The large productivity and wage gap between cities and countryside also drives a high volume of rural-urban migration. Lewis pointed out that, starting from a situation of $80 \%$ rural, the initial shift of some people from low-productivity agriculture to highproductivity urban employment is disequalizing. If the flow continues until the population is more than $50 \%$ urban, however, further migration is equalizing. This pattern is very evident in the history of the U.S., with inequality rising during the rapid industrialization period from 1870-1920, and then declining thereafter. So, the same market forces that have produced the rapid growth in China predictably led to higher 
inequality. But it is important to note that in China there are a number of government policies that exacerbate this tendency toward higher inequality and restrict some of the potential mechanisms that would normally lead to an eventual decline in inequality.

\section{B. Hukou restrictions on rural-urban migration}

Pre-reform China had a system that completely restricted people's mobility, and that system has only been slowly reformed over the past 25 years. Each person has a registration (hukou) in either a rural area or an urban area, and cannot change the hukou without the permission of the receiving jurisdiction. In practice cities usually give registration to skilled people who have offers of employment, but have generally been reluctant to provide registration to migrants from the countryside. Nevertheless, these migrants are needed for economic development, and large numbers have in fact migrated. Many of these fall into the category of "floating population." There are nearly 200 million rural residents who spend at least six months of the year working in urban areas (Figure 3). Many of these people have for all practical purposes moved to a city, but they do not have official registration. Beyond the floating population, there are tens of millions of people who have left rural areas and obtained urban hukous.

So, there is significant rural-urban migration in China, but it seems likely that the hukou system has resulted in less migration than otherwise would have occurred. There are several pieces of evidence to support this view. First, the gap in per capita income between rural and urban areas widened during the reform period, reaching a ratio of three to one (Sicular et al., 2007). Three to one is a very high gap by international standards. For example, Eastwood and Lipton (2004) give rural-urban income ratios for other Asian countries, which all fall between 1.3 and 1.8, with the lone exception of the Philippines where the gap is 2.2 to one. Second, manufacturing wages have risen sharply in recent years, at double-digit rates, so that China now has considerably higher wages than much of the rest of developing Asia (India, Vietnam, Pakistan, Bangladesh). This rise is good for the incumbent workers, but they are relatively high up in China's income distribution, so that the wage increases raise inequality. It is hard to imagine that manufacturing wages would have risen so rapidly if there had not been such controls on labor migration. Third, recent studies focusing on migrants have shown that it is difficult for them to bring 
their families to the city, put their children in school, and obtain healthcare. So, the growth of the urban population must have been slowed down by these restrictions.

In defense of the hukou system, it should be noted that China's urbanization so far has been a relatively orderly process. One does not see in China the kinds of slums and extreme poverty that exist in cities throughout Asia, Latin America, and Africa. Nevertheless, urbanization goes on: the urban share of China's population has risen from $20 \%$ to $40 \%$ during the course of economic reform. I conclude that the hukou system has slowed and distorted urbanization, without preventing it. The system has likely contributed to inequality by limiting the opportunities of the relatively poor rural population to move to better-paying employment.

\section{Land policy and corruption}

In the same way that people are either registered as urban or rural, land in China is zoned as either rural or urban. Within both locations, property rights over land are pretty good. In urban areas people can easily sell their land and buildings, or mortgage them to borrow. In rural areas, peasants have long-term tenure as long as they sow the land, but they cannot mortgage or sell the use rights. The biggest distortion, however, concerns moving land from rural to urban use. China is a densely populated, water-scarce country whose comparative advantage lies more in manufacturing and services than in agriculture. The fact that many peasants cannot earn a decent living as farmers is a signal that their labor is more useful in urban employment, hence the hundreds of millions of people who have migrated. But, at the same time, it is efficient to alienate some of the land out of agriculture for urban use.

In China, that conversion is handled administratively, requiring central approval. Farmers are compensated based on the agricultural value of the land. But the reason to convert land - especially in the fringes around cities - is that the commercial value of the land for urban use is higher than its value for agriculture. So, even if China's laws on land are followed scrupulously, the conversion does not generate a high income for the peasants. There are cases in which the conversion is done transparently, the use rights over the land auctioned, and the revenue collected put into the public budget to finance public goods. But still the peasants get relatively poor recompense. One government 
study found that $62 \%$ of displaced peasants were worse off after land conversion (Rural Development Institute, 2005).

Furthermore, one reads in the press of many cases where peasants complain and demonstrate because the conversions have not been done in a transparent way, and there are accusations of corruption lining the pockets of local officials. The government has published statistics on violent protests involving more than 100 people, and that number

grew steadily up to 2005 (84,000 incidents), before dropping a reported 20\% in 2006. The government has been taking a number of measures, which I will return to in the policy section below; the drop in 2006 in violent protests suggests that the government's actions may have improved the situation. But we can say that up until 2006, the way in which agricultural land was being converted to urban land probably contributed unnecessarily to increasing inequality. One of the good things about China is that virtually all peasants have land. If that asset could be used either as collateral for borrowing, or could be sold to provide some capital before migrants moved to the city, then it would have been helping those who were in the poorer part of the income distribution. The administrative, rather than market-based, conversion of land essentially reduced the value of the main asset held by the poor.

\section{Fiscal system and rural social services}

I noted above that one effect of market reform in China was to dramatically increase the return to education. This should be a positive development, as it indicates that there are good opportunities for skilled people and as it creates a powerful incentive for families to increase the education of their children. However, there needs to be strong public support for education and reasonably fair access to the system. Otherwise, inequality can become self-perpetuating: if only high-income people can educate their children, then that group remains a privileged, high-income group permanently. China is at some risk of falling into this trap, because it has developed a highly decentralized fiscal system in which local governments rely primarily on local tax collection to provide basic services such as primary education and primary health care. China in fact has one of the most decentralized fiscal systems in the world. 
China is much more decentralized than OECD countries and middle-income countries, particularly on the spending side. More than half of all expenditure takes place at the sub-provincial level. In part, the sheer size of the country explains this degree of decentralization, but the structure of government and some unusual expenditure assignments also give rise to this pattern of spending. Functions such as social security, justice, and even the production of national statistics are largely decentralized in China, whereas they are central functions in most other countries.

Fiscal disparities among subnational governments are larger in China than in most OECD countries. These disparities have emerged alongside a growing disparity in economic strength among the provinces. From 1990 to 2003, the ratio of per capita GDP of the richest to poorest province grew from 7.3 to 13. In China, the richest province has more than 8 times the per capita public spending than the poorest province. In the US, the poorest state has about 65 percent of the revenues of the average state, and in Germany, any state falling below 95 percent of the average level gets subsidized through the "Finanzausgleich" (and any receiving more than 110 percent gets taxed). In Brazil, the richest state has 2.3 times the revenues per capita of the poorest state (Dollar and Hofman, forthcoming).

Inequalities in spending are even larger at the sub-provincial level. The richest county, the level that is most important for service delivery, has about 48 times the level of per capita spending of the poorest county (Dollar and Hofman, forthcoming). These disparities in aggregate spending levels also show up in functional categories such as health and education where variation among counties and among provinces is large (Figure 4).

These differences in public spending translate into differences in social outcomes. Up through 1990, there were only modest differences across provinces in infant survival rate, but by 2000 there had emerged a very sharp difference, closely related to the province's per capita GDP. So too with the high-school enrollment rate: there used to be small differences across provinces. By 2003, high-school enrollment was nearing 100\% in the wealthier provinces while still less than $40 \%$ in poor provinces (Figure 5).

There is some redistribution within China's fiscal system, but not enough. Poor areas have very little tax collection and hence cannot fund decent basic education and 
health care. Some of their population will relocate over time. But for reasons of both national efficiency and equity, it would make sense for the state to ensure that everyone has good basic education and health care, so that when people move they come with a solid foundation of human capital.

China's highly decentralized fiscal system results in local government in many locations not having adequate resources to fund basic social services. As a consequence, households are left to fend for themselves to a remarkable extent. The average hospital visit in China is paid 60\% out-of-pocket by the patient, compared to 25\% in Mexico, $10 \%$ in Turkey, and lower amounts in most developed countries (Figure 6). Poor households either forego treatment or face devastating financial consequences. In the 2003 National Health Survey, $30 \%$ of poor households identified a large health care expenditure as the reason that they were in poverty.

The situation in education is similar. In a survey of 3037 villages in 2004, average primary school fees were 260 yuan and average middle-school fees, 442 yuan. A family living right at the dollar-a-day poverty line would have about 888 yuan total resources for a child for a year; sending a child to middle-school would take half of that. Not surprisingly, then, enrollment rates are relatively low in poor areas and for poor families.

\section{The trade balance and inequality}

The theme of this panel is "disparity,” and I have interpreted that to be largely about China and largely about long-term structural policies that have led to unnecessarily large disparity in China. But I also want to comment briefly on an important contemporary issue, the trade imbalance between China and the U.S., because ironically I think that the imbalance is exacerbating disparity in both countries.

The integration of a populous country such as China into the global economy inevitably imposes adjustment on every other country, including the U.S. Economic theory suggests that the U.S. economy and the global economy gain overall from the interaction with China, but that there will be individual winners and losers. Since China began opening up, and especially in the past 15 years, the global economy and the U.S.

economy have grown well, which supports the notion that there are overall benefits. The 
benefits to the U.S. come in various forms, including opportunities to buy low-cost imports of things China makes well, as well as opportunities to sell more of what the U.S. does well - aircraft is an obvious example, as are films, financial services, university education. The return to capital is high in China, so that Americans who own shares in multinational companies also benefit from the opening up.

However, it seems clear that the integration is putting a lot of strain on U.S. workers who have relatively low skills. It is hard to prove what the quantitative effect is, but it seems clear to me that integration with China (and other developing countries) has been a prime cause of rising inequality in the U.S. While there are great new opportunities for managers, bankers, university professors, and other high-skilled professionals, there are diminishing opportunities for manufacturing factory workers and others with medium skills.

This adjustment is inevitably difficult and naturally invites a discussion of policy options. One option, popular in some circles in the U.S., is to try to limit and control the trade and investment with China. This is inherently a conservative approach in that it tries to preserve the status quo. My reading of history is that trying to prevent adjustment by restricting trade fails to protect jobs in the long run, while leaving the country poorer and less able to assist people who need support. A progressive approach to adjustment focuses on services and safety nets that help workers adjust. One of the most obvious forms of safety net would be a national health insurance system not tied to employment that ensures that every family has access to decent health care and can keep that insurance if workers are temporarily unemployed or shift to a new job. A progressive income tax system is another obvious way to limit the effect of globalization on domestic income distribution. In the U.S., the reduced progressivity of the U.S. income tax has exacerbated rather than counteracted the disequalizing effect of globalization. A careful study of income distribution trends in all of the industrialized countries concluded that domestic policies were far more important that international trade in determining the final after-tax distribution of income (Smeeding 2005). A number of northern European countries have managed to put in place effective social protection systems that also keep the labor market flexible and the economy competitive. 
A lot of attention in recent years has focused on the trade imbalance between China and the U.S. China's overall trade surplus has only emerged in the past few years, and it is important to keep in mind that even with balanced trade China's integration into the global economy would inevitably put stress on low-skilled workers in the U.S. and other industrial countries. A progressive agenda of social protection is required whether trade is balanced or not. That said, the large trade deficit that the U.S. has developed and the large trade surplus that China has developed are a problem for the world economy. The imbalance at this magnitude is not sustainable, and it does accelerate the problems for low-skilled workers in the U.S. ${ }^{5}$ Adjustment is inevitably easier when it is gradual, so accelerating the adjustment is a real problem for American workers.

In my view the imbalance has both a demand side source and a supply side source. On the demand side, the U.S. followed the 9/11 attacks with very serious fiscal stimulus to the economy. This made sense as a temporary measure, but the structural deficit that the U.S. has put in place through tax cuts and expenditure increases is now a real problem. There is a lot of truth to the Chinese government argument that it will be difficult for the U.S. trade deficit to decline unless the U.S. government reduces its fiscal deficit (probably through some combination of tax increases and expenditure reductions). At the same time, there is also a supply-side problem. Productivity growth has been very rapid in China, and this requires at some point a real appreciation of the exchange rate to prevent an unhealthy trade surplus from developing. The real appreciation can occur either through general price inflation with a fixed exchange rate or through appreciation of the nominal exchange rate with price stability. Most economists today argue for nominal appreciation with price stability. A significant minority of prominent economists, however, disagree, and urge China to maintain its peg with the U.S. dollar.

The current situation puts China in a difficult spot. It is not fair to call China a currency manipulator. It opted for the pegged exchange rate over ten years ago and stuck with it through difficult times and good times. For much of the period that rate produced a relatively balanced trade account. And the stable peg to the dollar was certainly a factor of stability for the overall Chinese economy. Hence Chinese authorities are reluctant to give up something that has worked well. They are also spooked by what happened to Japan when it allowed a very large appreciation in the mid-1980s, leading to 
an asset bubble, its subsequent collapse, and ten years of lost growth. The current Chinese policy of allowing a very modest appreciation (so far, about $6 \%$ from the old peg) is something of a compromise.

The current situation is really not in China's interest. It is still a relatively poor country with lots of needs. The trade surplus means that China is exporting capital, which it needs itself. It has invested mostly in low-return U.S. bonds (the famous $\$ 1$ trillion of reserves). China's trade account is so stimulative of the economy, that it then has to reign in demand elsewhere. So, while the government is making some effort to address the problem of low social spending noted in the previous section, it is hampered in this by the hot state of the overall economy. Some further appreciation of the currency, which would tend to cool off the export sector, would open up space to expand spending on domestic needs. Also, one of the things China fears about currency appreciation is that it will choke off job creation. The export sector has been a good source of job creation in the past. However, in recent years it has not been a source of net job creation. China's manufacturing sector has become more capital intensive and in recent years has created few new jobs. According to official statistics, in the eight years ending in 2005 the industrial sector in China created fewer than 2 million new jobs per year, compared to nearly 7 million per year created in the services sector. So, a combination of exchange rate appreciation together with greater public spending on services could create more jobs than currently occurs. This policy could be designed to be equalizing compared to the current situation. The export boom benefits urban property owners and existing urban workers, while making it difficult for the government to increase public spending on rural development and social services. Exchange rate appreciation combined with more social spending could help address China's disparities.

But it is difficult to control the pace of appreciation. Despite capital controls, a lot of speculative capital is now flowing into China. Some further appreciation may encourage more inflows, exacerbating China's macroeconomic management challenges. Economists - who rarely agree on anything - are pretty much agreed that exiting from a fixed exchange rate system is tricky business. If it goes badly, it could have very negative effects on China and the world economy. 
What all this suggests is that in the dialogue between China and the U.S., it is useful to stress that the current situation is not in China's interest and is not sustainable. Reducing China's trade surplus would mean that China could put more of its resources into meeting its own domestic needs. The U.S. will have more credibility in the dialogue if it is taking concrete steps to increase savings in the U.S., including reducing the structural fiscal deficit. Finally, it is worth recognizing that the challenge China faces is very difficult, and that leading economists disagree about exactly how to proceed. Bashing China over the exchange rate issue is neither fair nor productive.

\section{Policies to reduce disparities}

While some increase in disparities was inevitable as China introduced market reforms, aspects of its policies discussed above tended to exacerbate rather than mitigate disparities. Hence, there are clear policy measures that China can adopt to limit or even reverse growing disparities. In recent years the government has started to move on these issues.

The most important issue is to facilitate rather than retard rural-urban migration, as the growing gap between rural living standards and urban living standards is the single greatest source of rising inequality. China has begun to modify the hukou system in various ways. For example, the Ministry of Finance has made it clear through a circular that local governments are responsible for providing public services to migrants, including education for their children and access to public health services. Some cities with labor shortages are welcoming permanent migrants and making it easy for them to register formally and get a full range of benefits. That said, it is not easy to change a deep-seated pattern of behavior. It is common for cities to have dual systems of benefits for formal residents versus recent migrants - even separate schools for migrant children, with inferior facilities and financing. Establishing equal services and legal rights for migrants is likely to take a decade or more. But it is important that the central government now recognizes that migration is a positive force for development and poverty reduction.

Migration would also be facilitated by truly developing a rural land market. If peasants could sell or mortgage their land use rights, that would enable them to finance 
rural investments, training, or a move to the city. The government is worried that too much land will move out of agriculture. This concern is probably overblown. The amount of land actually needed for urbanization is minor compared to China's agricultural land. Furthermore, there are market-based ways of intervening and ensuring adequate agricultural production. The problem with the current system is that it imposes a large inefficiency and cost on peasants, who are the relatively poor group in society. When land is alienated out of agriculture for urban use, the peasants currently get relatively little compensation. The government is very concerned about abuses in the land allocation system and has instituted close central government scrutiny of land conversions. There have also been ad hoc increases in payments to displaced farmers. But there is still a need for systemic reform of the rural land market.

Another obvious measure to address disparities in China is to ensure adequate funding for basic education and health in all rural areas. Many poor local governments cannot provide decent services based on their own tax revenue. For the rural residents who remain in agriculture as well as for those who later choose to move to cities, a good basic education is fundamental. Nine-two percent of the remaining poor in China have less than nine years of education; or to turn that around: among those with nine years or more of education, the poverty rate is a miniscule 2\%. Education is one of the key paths out of poverty. The government has recognized this and has greatly increased central government revenue to subsidize rural basic education. In the 2006 budget, provision was made to finance the elimination of tuition and fees for all rural students in the Western provinces. In the 2007 budget this was extended to all rural students in the Central and Eastern provinces.

The issue goes beyond school tuition and fees, however. They were an important obstacle, and if the government's new policies are implemented at the local level it will make a big difference. It remains the case, however, that local governments in wealthier counties will spend far more on basic education, so that there will still be a large disparity between quality of education in poor areas and quality in rich. China would need stronger equalizing transfers among locations to move toward the relatively small level of disparity observed in most middle-income and advanced economies. In addition to providing budget, the central government should create some strong accountability for 
local officials. In many countries these budget transfers are made conditional on outcome measures (naïve ones, such as enrollment rates, or ideally sophisticated ones such as test scores on standardized tests).

Rural public health is another important area where both more money and better design are needed. The government has initiated a small, pilot program for rural medical insurance. But the amounts contributed so far by the government are too small to have much effect on outcomes. The 2007 budget nearly doubled the funding for this program. But just as important will be improvements in design. Currently there are strong incentives for doctors to prescribe certain types of procedures for which they are well compensated (eg, there has been an alarming rise in caesarian deliveries in China). Simply increasing funding to the sector without reforming the incentives is not likely to lead to better health outcomes.

Progressive taxation and social protection payments are other ways that growing disparity can be controlled. The government abolished in 2004 the centuries-old agricultural tax, and that had a large and immediate impact on rural real incomes. China has introduced and strengthened a progressive income tax. Frankly, it is difficult to make personal income tax work well in a developing economy, but this at least lays a foundation for the future. On the social protection side, minimum support payments (dibao) have developed in recent years. As with other social expenditures, initially these were funded by local government leading to the anomaly that rich Beijing has high dibao payments for its formally registered residents, but nothing for migrants. And in most rural areas the payments are non-existent or trivially small. The 2007 budget also included a provision to provide central money for the rural social protection program to expand its geographic coverage.

A final point: in my view, the current trade surplus of China exacerbates disparities within the country. The dynamic export sector is no longer an important source of job creation; it is too capital intensive and has too rapid productivity growth. So, keeping this sector stimulated through a competitive exchange rate tends to drive up incomes of long-time urban residents who are already wealthy in China's context. The incipient overheating prevents the government from spending even more on education and health. The measures that I have outlined here - encouraging migration, reforming 
the rural land market, and strengthening rural education, health, and social protection would all be complemented by some further exchange rate appreciation. That by itself would tend to cool off the export sector. But the appreciation would make Chinese people as a whole wealthier and encourage consumption, which in every society is primarily composed of services. Services are more labor intensive than industry. The government could counteract any overall slowing of the economy with more public expenditure, especially on health and education. Their direct provision is more labor intensive than industry, and if greater public spending reduced vulnerabilities for households then they would be likely to spend more on private consumption as well. Simply put, a large trade surplus means that China is producing to meet other countries' needs; rebalancing toward the domestic market would make China produce more for its own peoples’ needs. 


\section{References}

Acharya, Shankar, Ahluwalia, Isher, Krishna, K.L., Patnaik, IIa., 2003. India: Economic Growth, 1950-2000. Available at

http://www.gdnet.org/pdf2/gdn_library/global_research_projects/explaining_grow th/India_Complete_31Mar04.pdf.

Barro, Robert J., Lee, Jong-Wha, 2000. International Data on Educational Attainment: Updates and Implications. NBER Working Paper No. 7911. Available at http://www.nber.org/papers/w7911.pdf.

Dollar, David and Bert Hofman, forthcoming. Intergovernmental Fiscal Reforms, Expenditure Assignment, and Governance. In, Jiwei Lou and Shuilin Wang, eds., China: Public Finance for a Harmonious Society

Dollar, David R., Hallward-Driemeier, Mary, Mengistae, Taye, 2005. Investment Climate and Firm Performance in Developing Economies. Economic Development and Cultural Change 54(1), 1-31.

Dollar, David R., Wei, Shang-Jin, 2006. Das Wasted Kapital. IMF Working Paper.

Eastman, R. and M. Lipton, 2004. Rural and Urban Income Inequality and Poverty: Does Convergence between Sectors Offset Divergence within Them? in G. A. Cornea, ed., Inequality, Growth and Poverty in an Era of Liberalization and Globalization, Oxford U. Press, 112-141.

Lardy, Nicholas R., 2002. The Economic Future of China. Available at http://www.asiasociety.org/speeches/lardy.html.

Lewis, W. Arthur. 1954. Economic Development with Unlimited Supplies of Labor. Manchester School.

Lin, Justin Yifu, 1988. The Household Responsibility System in China's Agricultural Reform: A Theoretical and Empirical Study. Economic Development and Cultural Change 36(3), S199-S224.

Lin, Justin Yifu, 1992. Rural Reforms and Agricultural Growth in China. The American Economic Review 82(1), 34-51.

Morrisson, Christian, Murtin, Fabrice, 2005. The World Distribution of Human Capital, Life Expectancy, and Income: a Multi-Dimensional Approach. Available at http://www.paris-jourdan.ens.fr/ydepot/semin/texte0506/MUR2005WOR.pdf. 
Ravallion, Martin, and Shaohua Chen, 2005. China’s (Uneven) Progress Against Poverty. Journal of Development Economics.

Rawski, Thomas G., 1994. Chinese Industrial Reform: Accomplishments, Prospects, and Implications. The American Economic Review 84(2), 271-275.

Roubini, Nouriel, and Setser, Brad, 2005. Will the Bretton Woods 2 Regime Unravel Soon? The Risk of a Hard Landing in 2005-2006. Available at http://www.frbsf.org/economics/conferences/0502/Roubini.pdf.

Sicular, T., X. Yue, B. Gustafsson, and S. Li, 2007. The Urban-Rural Income Gap and Inequality in China, Review of Income and Wealth, 53(1): 93-126.

Smeeding, T. M. (2002). "Globalization, Inequality and the Rich Countries of the G-20: Updated Results from the Luxembourg Income Study (LIS) and other Places.” Prepared for the G-20 Meeting, Globalization, Living Standards and Inequality: Recent Progress and Continuing Challenges, Sydney, Australia, 26-28 May, 2002. Mimeo.

Srinivasan, T.N., 2001. Indian Economic Reforms: Background, Rationale, Achievements, and Future Prospects. In: Narayana, N. S. S. (ed.) Economic Policy and State Intervention: Selected Papers of T. N. Srinivasan, Oxford and New York, Oxford University Press, pp.230-70.

Williamson, John, 2005. The Potential of International Policy Coordination. Peter G. Peterson Institute for International Economics Working Paper. Available at http://www.iie.com/publications/papers/williamson0305.htm.

World Bank, 2006. Governance, Investment Climate, and the Harmonious Society: Competitiveness Enhancements for 120 Cities in China. Report No. 37759-CN.

Zhang, Junsen, Yaohui Zhao, Albert Park, and Xiaoqing Song, 2005. Economic Returns to Schooling in Urban China, 1988-2001. Journal of Comparative Economics 33: 730-752.

Zhang, Xiaobo, and Kong-yam Tan, 2006. Incremental Reform and Distortions in China's Product and Factor Markets. World Bank Economic Review. 


\section{Table 1}

\begin{tabular}{clllll}
\multicolumn{1}{c}{ China } & & $\begin{array}{l}\text { Population } \\
\text { (millions) }\end{array}$ & $\begin{array}{l}\text { GDP p.c. } \\
\text { (2000 US\$) }\end{array}$ & $\begin{array}{l}\text { Infant mortality } \\
\text { (per 1000) }\end{array}$ & $\begin{array}{l}\text { Years of schooling } \\
\text { (adults above 25) }\end{array}$ \\
& 1990 & 1135 & 1597 & 38 & 5.2 \\
2005 & 1304 & 5879 & 26 & 5.7 \\
India & & & & & \\
& 1990 & 850 & 1701 & 80 & 3.7 \\
2005 & 1096 & 3118 & 61.6 & 4.8 \\
Bangladesh & & & & 2.2 \\
1990 & 104 & 1208 & 100 & 2.5 \\
2005 & 142 & 1786 & 56.4 & 3.3 \\
Indonesia & & & & 4.7 \\
1990 & 178 & 2267 & 60 &
\end{tabular}

Myanmar

$\begin{array}{lllll}1990 & 41 & \text { n.a. } & 91 & 2.1 \\ 2005 & 51 & \text { n.a. } & 75.6 & 2.4\end{array}$

Pakistan

$\begin{array}{lllll}1990 & 108 & 1561 & 100 & 2.3 \\ 2005 & 156 & 2149 & 80.2 & 2.5\end{array}$

Philippines

$\begin{array}{lllll}1990 & 61 & 3877 & 41 & 7.1 \\ 2005 & 83 & 4401 & 26 & 7.6\end{array}$

Thailand

$\begin{array}{lllll}1990 & 55 & 4552 & 31 & 5.4 \\ 2005 & 64 & 7649 & 18.2 & 6.1\end{array}$

Vietnam

$\begin{array}{lllll}1990 & 66 & 1212 & 38 & 3.8\end{array}$

$\begin{array}{lllll}2005 & 83 & 2739 & 17.4 & \text { n.a. }\end{array}$

RODA7

$\begin{array}{lllll}1990 & 613 & 2209 & 69 & 3.5 \\ 2005 & 799 & 3247 & 45 & 4.1\end{array}$

Sources: World Development Indicators; Barro and Lee (2000). 
Table 2

\begin{tabular}{lcccc} 
& \multicolumn{2}{l}{ Average import tariff (percent) } & \multicolumn{2}{l}{ Annual manufacturing wages (US\$) } \\
& 1990 & 2004 & $1980 \mathrm{~s}$ & 2000 \\
Bangladesh & 94 & 18 & 556 & 671 \\
India & 82 & 28 & 1035 & 1192 \\
Pakistan & 65 & 16 & 664 & 844 \\
Vietnam & n.a. & 14 & n.a. & 711 \\
China & 40 & 10 & 472 & 1766 \\
Thailand & 40 & 14 & 2305 & 2851 \\
Philippines & 28 & 6 & 1240 & 2376 \\
Indonesia & 21 & 7 & 898 & 3054
\end{tabular}

Source: UNCTAD TRAINS database; World Development Indicators. 
Table 3

Average days to claim Output lost to power

Imports from customs

outages (percent of sales)

\begin{tabular}{|c|c|c|}
\hline Bangladesh (2002) & 10.6 & 2.8 \\
\hline India (2002) & 6.6 & 7.9 \\
\hline Indonesia (2003) & 4.8 & 3.3 \\
\hline Pakistan (2002) & 17.1 & 4.9 \\
\hline Philippines (2003) & 7.2 & 5.9 \\
\hline Thailand (2004) & 3.7 & 1.4 \\
\hline Vietnam (2005) & 3.7 & 1.3 \\
\hline \multicolumn{3}{|c|}{ Coastal China (2005) } \\
\hline Hangzhou & 3.5 & 0.0 \\
\hline Jiangmen & 1.7 & 2.2 \\
\hline Qingdao & 2.0 & 1.1 \\
\hline Shantou & 1.8 & 0.0 \\
\hline Suzhou & 2.6 & 2.2 \\
\hline Weihai & 3.6 & 0.5 \\
\hline \multicolumn{2}{|c|}{ Average of six Chinese cities 3.2} & 1.0 \\
\hline
\end{tabular}




\section{(3igure 1. GDP growth and poverty decline}

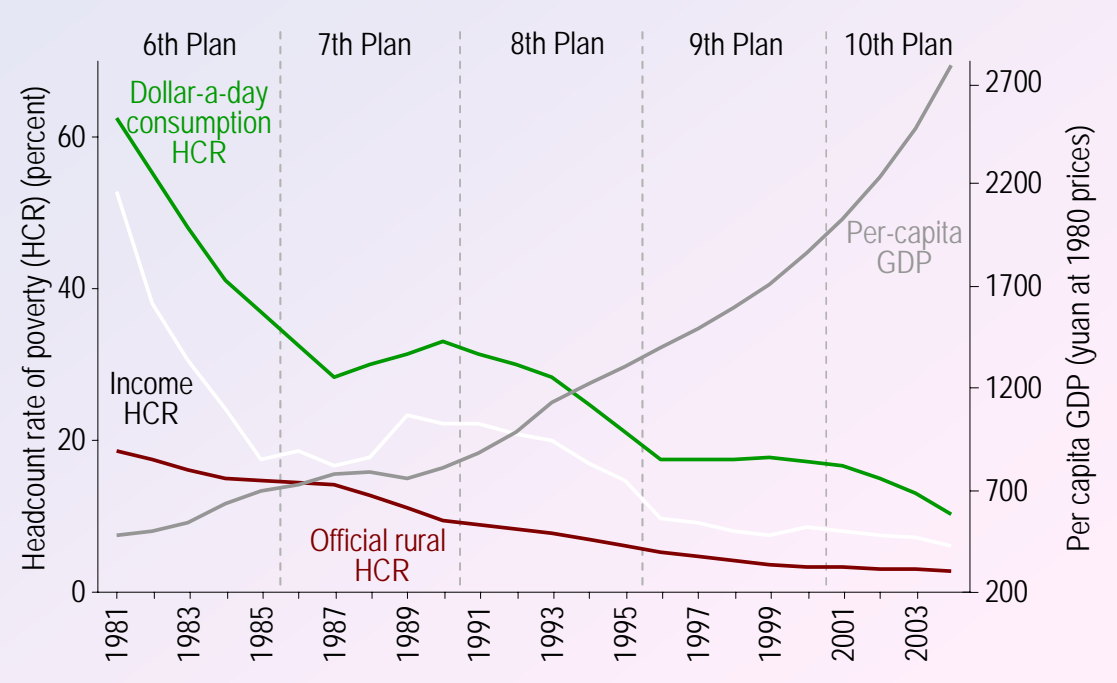

Source: Ravallion and Chen (2005) updated with NBS rural and urban household surveys.

\section{(52) Figure 2. Returns to education have increased}

Annual returns to schooling in urban areas as a percent of annual wages

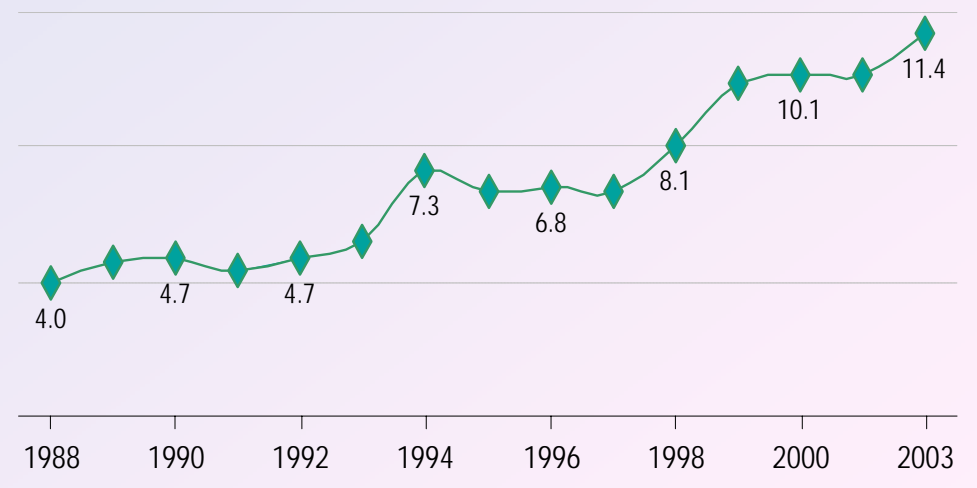

Source: Zhang et al. (2005). 


\section{(3) Figure 3. Rural population is moving to cities}

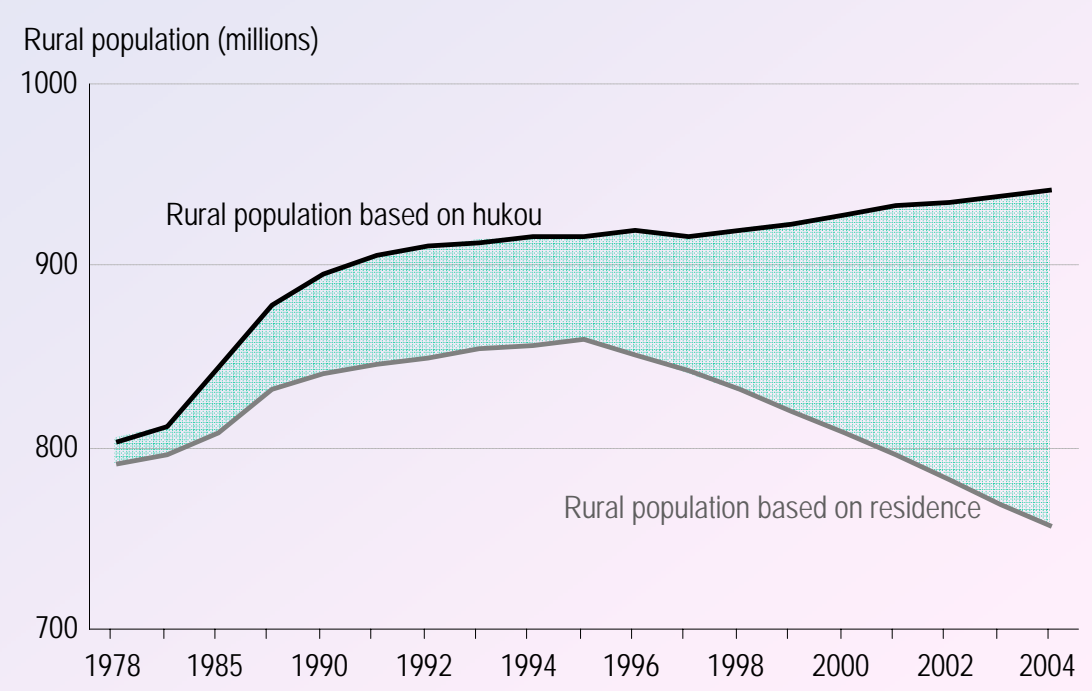

Source: National Bureau of Statistics.
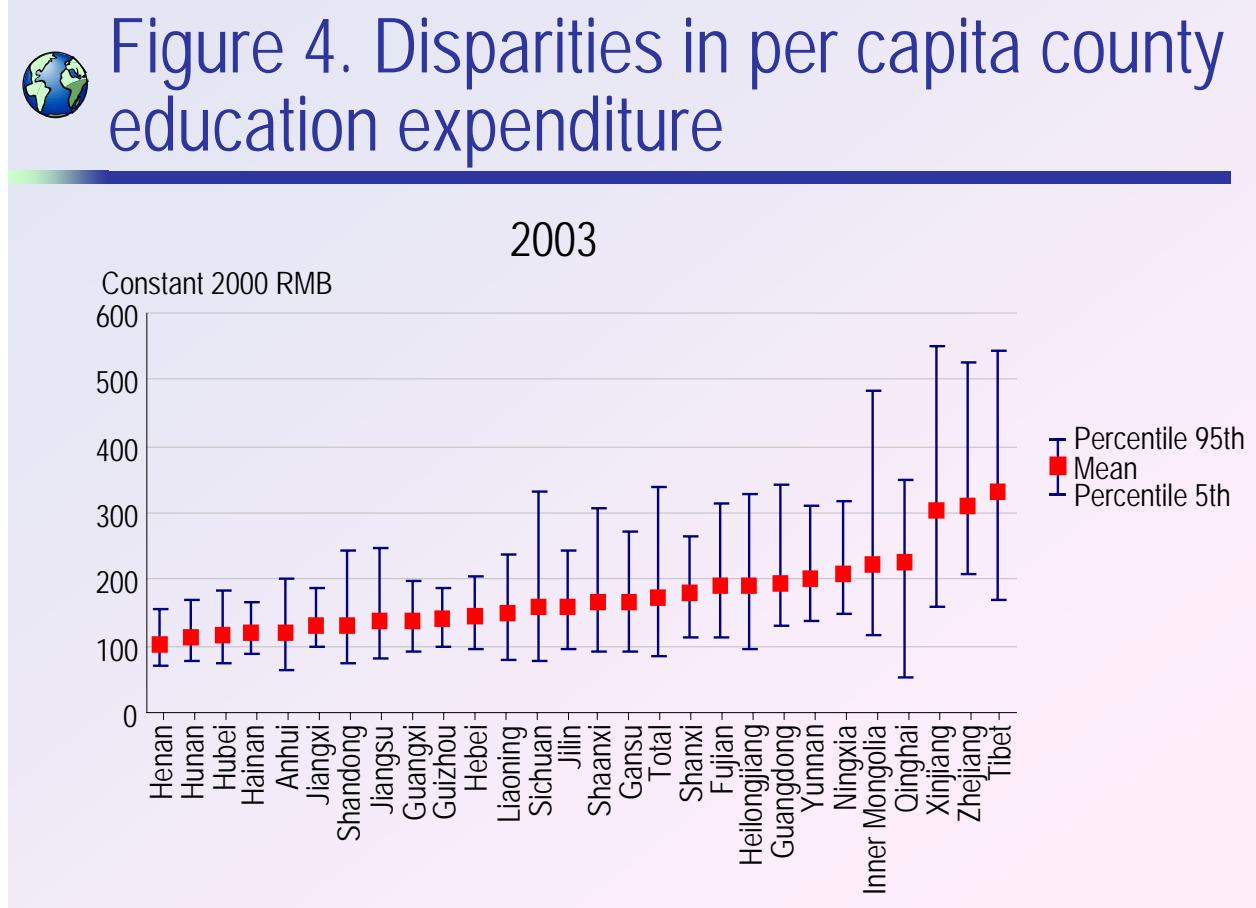

Source: Dollar and Hofman (forthcoming). 


\section{Figure 5. Education inequality has risen}

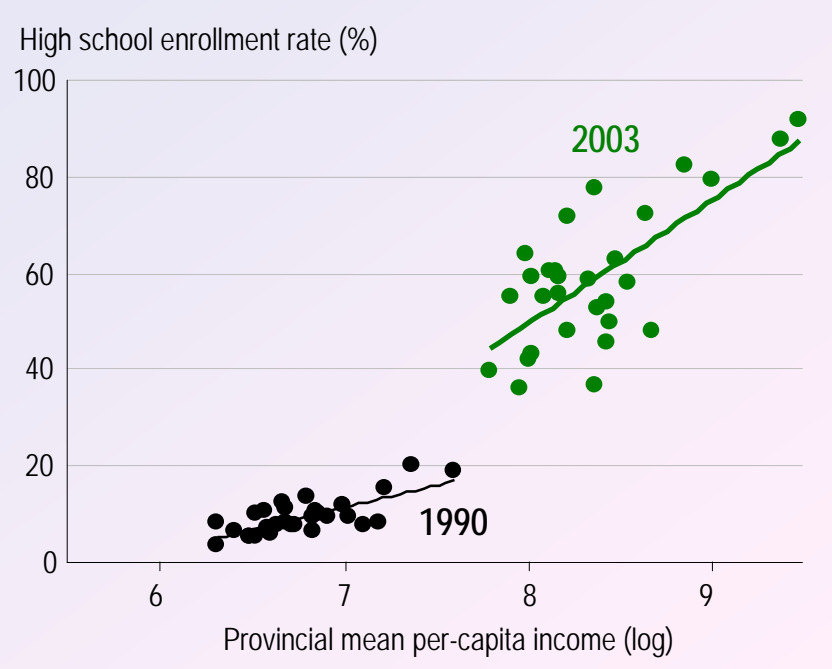

Source: China Human Development Report.

\section{(58) Figure 6. Unaffordable hospital care in China}

\section{Both lack of insurance, and costly care,} contribute to China's unaffordable hospital care

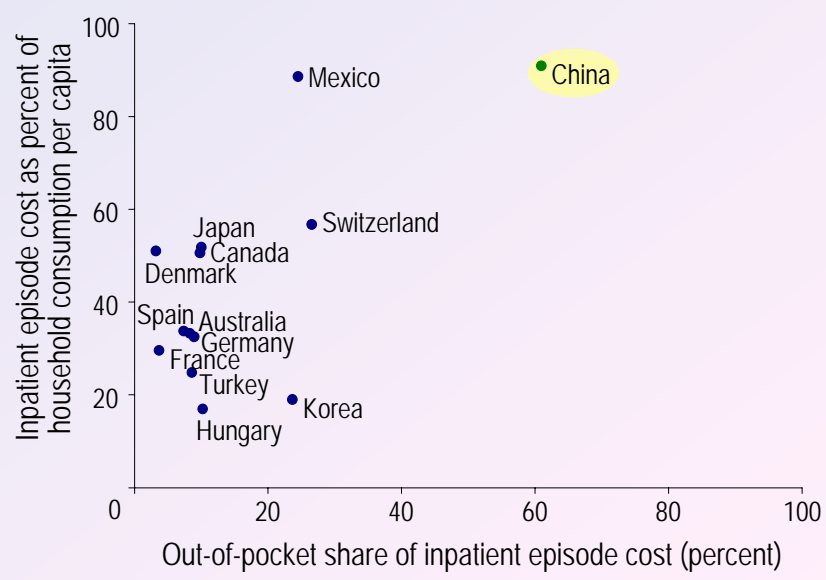

Source: OECD health database and China health statistical digest. 


\section{End Notes}

\footnotetext{
${ }^{1}$ Early stages of China's reform are described in Lin (1988) and Lin (1992). See Rawski (1994) on the industrial reforms in the 1990s.

${ }^{2}$ Lardy (2002) analyzes the importance of liberalizing foreign trade and investment for China’s modern development.

${ }^{3}$ Dollar, Hallward-Driemeier, and Mengistae, 2005, show that these investment climate indicators affect firm productivity and profitability in a study covering Bangladesh, China, India, and Pakistan.

${ }^{4}$ India’s reform efforts are described in Acharya et al., 2003; and Srinivasan, 2001.

${ }^{5}$ For analysis of why the trade imbalance is not sustainable and how it might unwind unpleasantly, see Roubini and Setser, 2005, or Williamson, 2005.
} 